\title{
症例
}

慢性透析患者に合併した早期胃癌に対し腹腔鏡下胃局所切除術を 施行した 1 例

\author{
木沢記念病院外科 \\ 山内希美田辺博可知宏隆
}

\section{A Case of Laparoscopic Local Resection for Early Gastric Cancer in a Hemodialysis Patient}

\author{
Kimi YAMAUCHI, Hiroshi TANABE and Hirotaka KACHI
}

\section{Department of Surgery, Kizawa Memorial Hospital}

\begin{abstract}
慢性透析患者に発症した早期胃癌に対しLesion Lifting法による腹腔鏡下胃局所切除術を施行した 1 例を経験 したので報告する。症例は68歳, 男性, 糖尿病性腎症にて体外超滤過法を受けていた。腹部膨満感が出現したた め上部消化管内視鏡検查を施行したところ胃体下部前壁に深達度 $m$, II 型胃癌が発見された。術前病変部をマー キングし, 腹腔鏡下にLesion Lifting法を用い病変部を切除した。手術時間は65分, 病理組織診断は深達度mの印 環細胞癌であった。早期胃癌に対しEMRは広く行われているが, 切除範囲や組織型により適応が限定される場合 がある。これに対して腹腔鏡下胃局所切除術は十分な切除が可能となる。われわれは深達度m, 陥凹性病変であ れば15mm以下, 潰瘍を伴わないことを条件に腹腔鏡下胃局所切除術を施行している。今回の症例は透析を行って おり，手術侵襲を軽減する意味でも本術式は利点が多く，有用な治療法と考えられた。
\end{abstract}

索引用語：腹腔鏡下手術 (Laparoscopic surgery), 胃局所切除 (Lesion lifting method), 慢性透析 (Hemodialysis)

\section{緒言}

近年, 人口の高齢化や糖尿病などの増加で慢性 腎不全の発生率が高くなり透析患者数は増加する 傾向にある。一方, 透析患者は悪性腫瘍の発生率 が高いとの報告があり, 特に消化器癌の発生率は 高いと報告されている1)。一方, 消化器外科におけ る治療面からはより低侵襲および術後のQOLを 目的とした腹腔鏡下手術が普及し，消化器癌に対 しても積極的に取り組む施設が増加しつつあ る2)。今回われわれは糖尿病性腎症にて体外超滤 過法にて加療中に早期胃癌と診断され，腹腔鏡下 胃局所切除を施行し良好な経過を得た 1 例を経験 したので若干の文献的考察を加えて報告する。

\section{症例}

症例：68歳, 男性。

主訴：全身浮腫, 腹部膨満感。

既往歴：糖尿病, 高血圧, 糖尿病性腎症。

現病歴：糖尿病性腎症によるネフローゼ症候群 のため1997年 7 月 4 日より体外超濾過法にて週 3 回, $1300 \mathrm{ml} /$ 回の除水を開始した。1997年 7 月末日 より腹部膨満感が出現したため, 上部消化管内視 鏡検查を施行したところ胃体下部前壁に陥凹性病 変を認め, 生検にて印環細胞癌と診断されたため 手術目的にて外科へ紹介となった。

入院時現症：血圧190/90, 脈拍66/分, 整。眼球 結膜に黄染は認めず，眼瞼結膜に貧血を認めた。 
Tab. 1 Laboratory data on admission

$\begin{array}{lrllrl}\text { WBC } & 4800 & / \mathrm{mm}^{3} & \text { BUN } & 36.7 & \mathrm{mg} / \mathrm{dl} \\ \mathrm{RBC} & 318 \times 10^{4} & / \mathrm{mm}^{3} & \mathrm{Cr} & 2.3 & \mathrm{mg} / \mathrm{dl} \\ \mathrm{Hb} & 9.9 \mathrm{~g} / \mathrm{dl} & \mathrm{UA} & 8.9 & \mathrm{mg} / \mathrm{dl} \\ \mathrm{Ht} & 30.3 & \% & \mathrm{Na} & 140 & \mathrm{mEq} / \mathrm{l} \\ \mathrm{Plt} & 19.1 \times 10^{4} & / \mathrm{mm}^{3} & \mathrm{~K} & 6.0 & \mathrm{mEq} / \mathrm{l} \\ \mathrm{TP} & 4.9 \mathrm{~g} / \mathrm{dl} & \mathrm{Cl} & 108 & \mathrm{mEq} / \mathrm{l} \\ \text { Alb } & 2.1 & \mathrm{~g} / \mathrm{dl} & \mathrm{T}-\mathrm{CHO} & 259 & \mathrm{mg} / \mathrm{dl} \\ \mathrm{T}-\mathrm{bil} & 0.23 & \mathrm{mg} / \mathrm{dl} & \mathrm{Fe} & 109 & \mu \mathrm{g} / \mathrm{dl} \\ \mathrm{D}-\mathrm{bil} & 0.09 & \mathrm{mg} / \mathrm{dl} & \mathrm{Ca} & 3.9 & \mathrm{mEq} / \mathrm{l} \\ \text { GOT } & 19 & \mathrm{IU} / 1 & \mathrm{CRP} & 0.33 & \mathrm{mg} / \mathrm{dl} \\ \text { GPT } & 22 & \mathrm{IU} / 1 & \text { FBS } & 139 & \mathrm{mg} / \mathrm{dl} \\ \text { LDH } & 404 & \mathrm{IU} / 1 & & & \\ \text { ALP } & 186 & \mathrm{IU} / 1 & & & \\ \text { r-GPT } & 38 & \mathrm{IU} / 1 & & & \end{array}$

下腿に浮腫, 慢性湿疹を認める。胸部に異常なく, 腹部は軟であったがやや膨隆していた。

入院時血液生化学検查：末梢血にて軽度の貧血 を認め, 生化学検查にて低タンパク血症および腎 機能障害を認めた（Tab. 1)。

胸部単純 $\mathbf{X}$ 線検查: 胸水の貯留は認めず, CTR50.5\%であった。

上部消化管内視鏡検查：胃体下部前壁に約 15 $\mathrm{mm}$ の陥凹性病変を認め, 同部よりの生検で GroupVと診断された（Fig. 1)。

以上より深達度mのIIc型早期胃癌と診断し, 手 術 1 週間前より体外超濾過法より血液透析に変更 し手術に備えた。

手術所見：1997年 8 月 11 日, 全身麻酔下にて腹 腔鏡下手術を施行した。臍上部より穿刺法にて気 腹し, 同部より腹腔鏡を挿入した。上腹部正中よ りやや左側に $12 \mathrm{~mm} ト$ ロカールを挿入し, 右側腹 部に $5 \mathrm{~mm}$ トロカールを挿入した。右胃大網動静 脈の分枝をクリッピングしながらハーモニック・ スカルペル (LCS) を用いて大網を切開した。小 弯側も同様にクッピイング後LCSを用い切開を 加之た (Fig. 2a)。術中上部消化管内視鏡を使用 し, 病変部に住友べーリンガーのT-Barを挿入し 確実に病変部を挙上した (lesion lifting法) (Fig. 2b)。病変部より切除線が十分離れるようにして ENDO-GIAを使用し, 胃局所切除術を施行した

(Fig. 2c)。切除組織はENDO-CATCHに収納 し, 臍上部より摘出した $($ Fig. $2 d)$ 。上部消化管内 視鏡にて胃内腔の狭窄がないことを確認し, Winslow孔にドレーンを留置し手術を終了した。手術

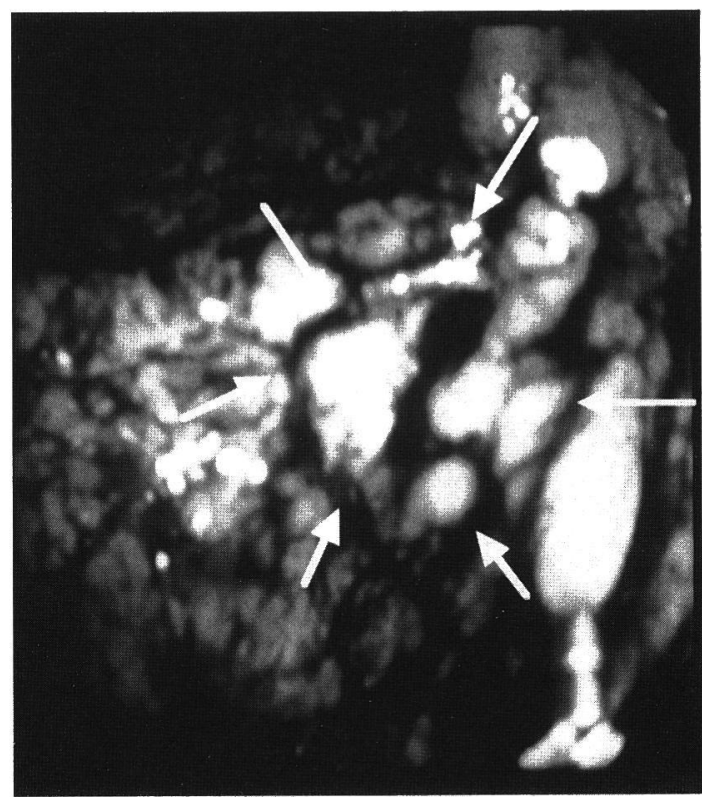

Fig. 1 Upper gastrointestinal findings:mucosal cancer $15 \mathrm{~mm}$ in diameter was found without ulceration.

時間は 1 時間 5 分であり, 出血量は極少量であっ た。

摘出標本：クリップの中央に最大径 $15 \mathrm{~mm}$ の陥 凹性病変を認め, 病変部より水平断端距離は 8 mm以上確保されている (Fig. 3)。

病理組織検查所見：摘出標本の病理組織学的検 討では深達度mの印環細胞癌と診断され, INF $\beta$, ly0, v0であり切除断端に癌は認められなかった

(Fig. 4 )。

術後第一病日より血液透析を開始し, 術後 1 週 間より体外超濾過法を週 3 回にて再開した。術後 第 5 病日より摂食を開始, 第14病日に退院となっ た。

\section{考察}

日本の透析患者は1985年から急速に増加の傾向 をたどり，1994年末で 14 万 3 千人を超え，年間 1 万人ずつ増加していると報告されている3)。透析 患者の原疾患では慢性腎炎が $59 \%$ と最も多く, 今 回経験したような糖尿病性腎症は $18 \%$ を占めると されている4。

透析患者において悪性腫瘍の発生率が高いこと 

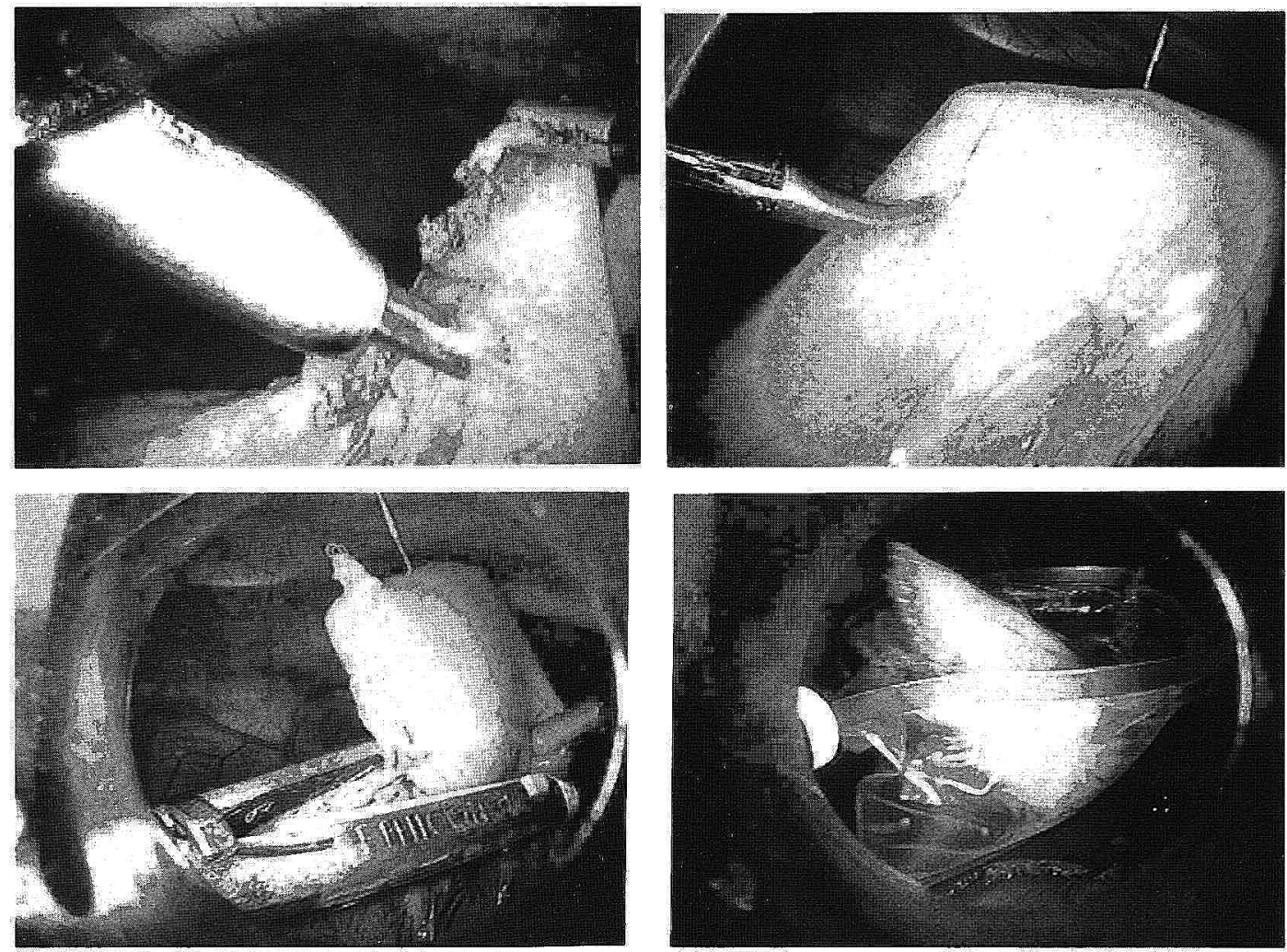

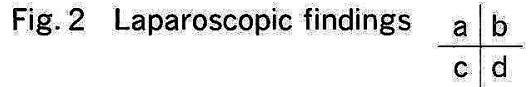

a : Mager and minor omentum was cut with laparosonic coagulating shears.

$\mathrm{b}$ : The cancerous lesion was left up with T-Bar.

c: The lifted local portion was cut out with ENDO-GIA.

d: The resected specimen was put in ENDO-CATCH and taken out.

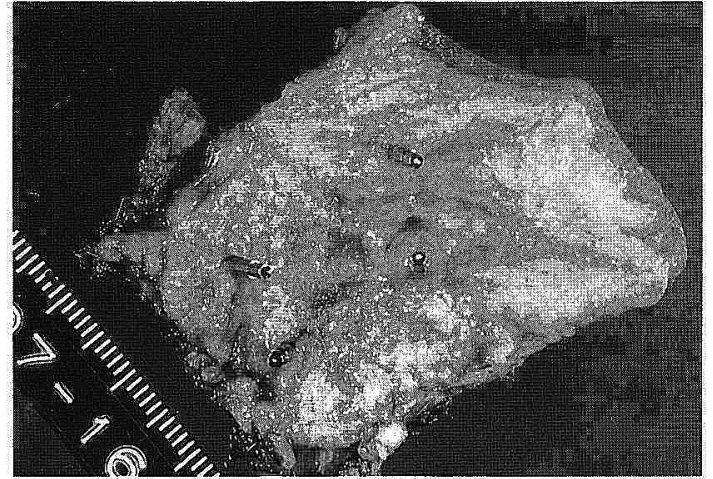

Fig. 3 The cancerous lesion of laparoscopic local resection was completry resected.

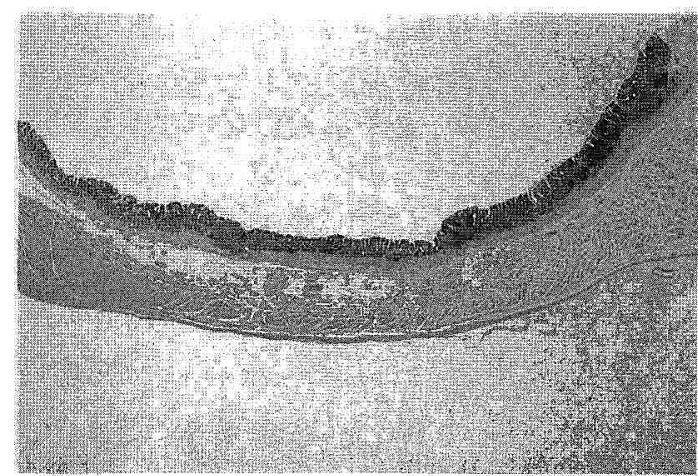

Fig. 4 Pathological findings was mucosal cancer of signet ring cell type.
は以前より多くの報告があり ，透析患者10万人 対476人であることから，一般住民の1.3倍と言わ
れている1)。悪性疾患の発見される時期について 言えば，透析尊入後に診断された悪性腫瘍症例の 
jち, 導入後 1 年以内に悪性腫瘍の発見されるこ とが $28 \%$ 存在することから，これらの症例はす でに担癌状態で透析に導入された可能性も高いと の報告もある ${ }^{6}$ 。

透析患者に悪性疾患が多く発見される原因とし ては尿毒症性代謝物質の影響や細胞性免疫能の低 下の関与が報告されてきた。尿毒症性物質として はニトロソ化合物の関与が指摘され, 透析患者の 消化管内にはジメチルアミンとそのニトロソ化合 物であるニトロソジメチルアミンの濃度が高いと の報告もある7)。細胞性免疫能の低下の原因とし ては患者血液中への免疫抑制物質の蓄積, 透析膜 からの溶出物質が考えられている ${ }^{8)}$ 。

維持透析患者においては消化器系の不定愁訴を 訴えるものが多く，近年は内視鏡を含めた消化器 系検査により消化器癌の発見される頻度が高く, なかでも胃癌は透析患者の悪性腫瘍のうち $26.6 \%$ を占めており最も発生率が高いと報告されてい

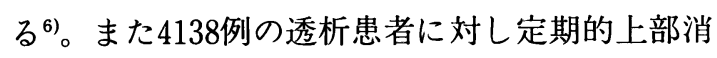
化管造影検查を 2711 例 (66\%) に施行したところ, 胃癌の発見率は $0.59 \%$, 早期胃癌の発見率は 0.41 \%であり 9), 一般検診による胃癌の発見率 $0.1 \%$, 早期胃癌の発見率 $0.05 \%{ }^{10}$ に比較すると高い発生 率が認められている。これは透析患者には悪性腫 瘍が多発するとの見解からの積極的な検査の結果 とも考えられる。

本症例も糖疗病性腎症によるネフローゼ症候群 のため1997年 7 月 4 日より体外超滤過法を開始後 1 カ月に満たない時期に胃部不快感を訴えたため 上部消化管内視鏡検查を施行し，胃体下部前壁に 病変を発見したものであった。

一方，透析患者に限らず近年の胃癌検診の普及 や内視鏡診断技術の発展により，早期胃癌の発見 率が急速に上昇している11。したがってこうした 診断技術の進歩に伴い治療にも変化がみられる。 病巣が粘膜内に限局しているようなものに対して は内視鏡的胃粘膜切除術 (EMR) が進められ良好 な成績をおさめているが12)，長径10mmを超える 病変の初回完全切除率は $52.9 \%$ と低下することが 指摘されている11)。そうした症例に対して初回手 術にて根治性が得られ, 低侵襲でかつ術後のQOL を目的とした腹腔鏡下手術が急速に普及し始めて
いる。

腹腔鏡下手術の利点は(1)水平方向, 垂直方向と も十分なsurgical marginを一括切除で確保でき, より詳細な病理組織診断が可能となる点, (2)第一 群で最も近位のリンパ節のサンプリングが可能で ある点, (3)EMRでは切除が困難である占拠部位の ものにも施行が可能である点 ${ }^{13)}$, (4)根治性, 低侵襲 性, 臟器温存性を併せ持つ点, (5)術後疼痛が少な く, 早期退院, 早期社会復帰が可能である点など である2)。EMRでは腫瘍径の大きなものは分割切 除の可能性も高くなり, 分割切除後再構築が必要 となるが11), 一括切除では再構築の必要もなく組 織学的評価が正確に可能となる。

胃癌の組織型については分化度の低い腫瘍の進 展形式からみると, 切除断端までの距離を十分に 確保しないと危険であるとの認識から ${ }^{14)}$ 多くの施 設ではEMRの適応を高分化型に限って施行して いる。また未分化癌では非連続的な病巣の進展を とる場合があり ${ }^{15)}$, こうした場合は一括切除での み正確な組織診断が可能になると報告されてい る ${ }^{2)}$ 。横山ら ${ }^{16)}$ はEMRにて不完全切除および分割 切除に終わった $10.7 \%$ に遺残再発を認めたと報告 し, 腫瘍径や深達度の点でも根治手術が可能であ ると言う点で腹腔鏡下胃局所切除は有効であると 報告している。

当院でも腹腔鏡下胃局所切除の適応を深達度 $\mathrm{m}$ であること, 隆起性病変であれば $25 \mathrm{~mm}$ 以下, 陥凹 性病変であれば $15 \mathrm{~mm}$ 以下, 潰瘍を伴わないこと を条件に施行している。また病変部をワイヤーで 固定された小金属棒で挙上させるlesion lifting 法 ${ }^{17)}$ は, 金属棒より十分な距離を離し, 粘膜面が滑 り落ちて病変部が切除線に近づくことがなく, 確 実に病変部を切除でき, 簡便で有効な術式と思わ れる。

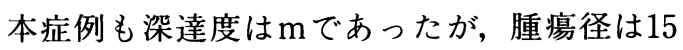
$\mathrm{mm}$ であり, 組織型も印環細胞癌と低分化型であ ったため, lesion lifting法を用いて腹腔鏡下胃局 所切除を施行した。透析患者の待期手術後の合併 症として, 創部感染, 低P血症による意識障害, 高 K血症, 心不全, 敗血症などが報告されているが4), 術後合併症を呈することもなく良好な経過を得る ことができた。 


\section{結 語}

今回われわれは糖尿病性腎症によるネフローゼ 症候群ため体外超濾過法にて加療中の早期胃癌症 例に腹腔鏡下胃局所切除術を施行した。腹腔鏡下 胃局所切除術は侵襲が少なく，合併症を有した患 者に対しても安全で有効な術式と思われここに報 告した。

\section{文献}

1）吉田克法，岡島英五郎：透析患者の悪性腫瘍。診 断と治療 $83 ： 525-530,1995$

2）小林利彦, 櫻町俊二，木村泰三：胃癌に対する腹 腔鏡下の局所切除術一当科の現況と手術成績か らみた問題点一．消内視鏡 9:303-308，1997

3）石川 勲：透析腎と腎癌. Molecular Medicine $32: 1170-1178,1995$.

4）添田耕司，磯野可一：慢性腎不全透析患者におけ 万急性腹症。外科診療 $8: 965-974$

5）宍戸 洋，二木 源，鈴木一之他：維持透析患者 にみられた悪性腫瘍例の検討(第 2 報)。腎と透析 $28: 248-252,1990$

6）小高通夫：わが国の透析療法の現況。透析会誌 $22: 221-304,1989$

7) Lele PS, Dunn SR, Simenhoff ML, et al:Evidence for generation of the precartinogen nitrosodimethylamine in the small intestine in chronic renal failure. Kidney Int $24: 229,1983$
8）杉本久之，秋山暢夫：長期透析において新たに惹 起される病態・診断とその対策・透析患者におけ る悪性腫場. Medical Practice 5：1926-1928, 1988

9）金 昌雄：透析患者の悪性腫瘍一診断と治療一. 臨透析 $10 ： 767-771,1994$

10）多賀須幸男，山崎忠男：XI腫瘍一胃癌Gastric cancer - A comprehensive review on epidemiological and clinical data and results of treatments in Japan. 日臨51：713-726, 1993

11）大谷吉秀, 大上正裕, 久保田哲朗他：早期胃癌に 対する腹腔鏡下手術。胃と腸 $31 ： 1121-1128,1996$

12) Tada M, Murakami A, Karita M, et al: Endoscopic resection of early gastric cancer. Endoscopy $25: 445-450,1993$

13）比企能樹, 嶋尾 仁, 小林伸行他：消化器悪性疾 患に対する腹腔鏡下手術応用の可能性，とくに早 期胃癌について。消内視鏡 $6: 1374-1380 ， 1994$

14）柳井秀雄, 藤村 寛, 相部 剛他：20MHzの超音 波プローブによる胃粘膜筋板の描出。日消病会誌 $88: 2725,1991$

15）三隅厚信，水本誠一，原田和則他：胃癌に対する 粘膜切除術。外科54：1304-1314，1992

16）横山伸二, 多幾山渉, 久保義郎他：胃癌に対する 腹腔鏡下胃局所切除術一手術成績からみた適応 と問題点一。消内視鏡 $9: 309-315,1997$

17）大上正裕, 大谷吉秀, 久保田哲朗他：早期胃癌に 対する腹腔鏡下手術。日臨54：113-117，1996 